\title{
Protein metabolism in growing lambs given fresh ryegrass (Lolium perenne) - clover (Trifolium repens) pasture ad lib
}

\section{Endocrine changes, glucose production, and their relationship to protein deposition and the partition of absorbed nutrients}

\author{
BY T. N. BARRY AND T. R. MANLEY \\ Invermay Agricultural Research Centre, Private Bag, Mosgiel, New Zealand
}

AND CAROLYNE REDEKOPP

Department of Endocrinology, Princess Margaret Hospital, Christchurch, New Zealand

\author{
AND S. R. DAVIS AND R. J. FAIRCLOUGH \\ Ruakura Research Centre, Hamilton, New Zealand \\ AND K. R. LAPWOOD \\ Massey University, Palmerston North, New Zealand
}

(Received 13 March 1981 - Accepted 29 October 1981)

\begin{abstract}
1. Glucose metabolism and changes in the concentrations of several hormones in jugular plasma were measured in growing lambs fed on fresh pasture ad lib. One group of lambs acted as control while the second received a continuous abomasal infusion supplying $44 \mathrm{~g}$ sodium caseinate $+0.5 \mathrm{~g}$ L-methionine/d.

2. Hormone concentrations were determined by radioimmunoassay procedures and glucose irreversible loss measured from continuous infusion of $\mathrm{D}-\left[\mathrm{U}-{ }^{14} \mathrm{C}\right] \mathrm{glucose}$.

3. Protein infusion increased plasma concentrations of insulin, glucagon and thyroxine $\left(T_{4}\right)$, depressed those of growth hormone, prolactin and somatostatin and had no effect on triiodothyronine $\left(T_{3}\right)$ concentrations. Cortisol concentrations also tended to be slightly higher in the plasma of protein-infused lambs.

4. Increases in herbage intake within the ad lib. range were associated with increases in plasma insulin and glucagon concentrations and decreases in growth hormone concentration, and it is suggested that these effects could be mediated in part by the accompanying increases in protein absorption from the intestines. $T_{\text {he }} T_{4}: T_{3}$ value also decreased with increasing herbage intake, and it is suggested this was due to conversion of $T_{4}$ to $T_{3}$.

5. After correction by covariance to equal herbage intake, rates of irreversible glucose loss for control and protein-infused lambs were $9 \cdot 2$ and $10.0 \mathrm{mg} / \mathrm{min}$ per $\mathrm{kg}$ body-weight ${ }^{0 \cdot 75}$. It was calculated that respectively $0 \cdot 12$ and 0.19 of the total glucose production in control and protein-infused lambs could be accounted for by net synthesis from protein.

6. It was concluded that changes in the circulating concentration of several hormones in protein-infused compared with control lambs were likely to have been implicated in protein deposition forming a greater proportion of energy retention in the infused lambs $(0.41$ v. 0.27$)$.
\end{abstract}

Abomasal infusion of casein + methionine in growing lambs fed on fresh ryegrass (Lolium perenne) - clover (Trifolium repens) pasture $a d$ lib. markedly increased protein depostion in wool and in body tissues (Barry, $1981 \mathrm{a}$ ). A greater proportion of total energy deposited was in the form of protein and less in the form of fat in the protein-infused compared with control lambs. The effects of the protein infusion on glucose production and plasma concentration of several hormones in the same animals are reported in the present paper, and discussed in relation to the increased protein deposition and changed partition of absorbed nutrients in protein-infused compared with control lambs.

Thyroxine is essential for wool growth (Ferguson et al. 1965), and in ruminants glucagon and insulin respectively stimulate gluconeogenesis in the liver and protein deposition in 
peripheral tissues (Bassett, 1975). As insulin secretion in sheep is stimulated by protein absorption from the intestines (Bassett et al. 1971) it does seem that changes in the endocrine system induced by increased protein absorption could be important in changing the partition of absorbed nutrients. Particular attention has therefore been attached to relationships between endocrine measurements and both protein deposition $(\mathrm{g} / \mathrm{d})$ and protein energy as a proportion of total energy deposited.

Absorbed amino acids can also be metabolized to glucose through gluconeogenesis in the liver, and Clark et al. (1977) have calculated a maximum production of $570 \mathrm{~g}$ glucose $/ \mathrm{kg}$ casein if the casein was used only for gluconeogenesis. A secondary objective was therefore, to measure rates of glucose production.

It was concluded that increasing protein absorption from the small intestine produced major changes in the endocrine system which in turn were likely to have enhanced both wool and body protein deposition.

\section{MATERIALS AND METHODS}

\section{Animals and diets}

Glucose production and endocrine measurements were made on the same animals as used by Barry $(1981 a$ ). Young growing lambs of initial weight $16.5 \mathrm{~kg}$ were fed on fresh ryegrass-clover pasture ad lib. for 12 weeks, with each daily feed offered as equal portions at 09.00 and 16.00 hours. All twenty-five lambs were fistulated in the abomasum. Thirteen lambs received a continuous abomasal infusion supplying $44 \mathrm{~g}$ sodium caseinate $+0.5 \mathrm{~g} \mathrm{~L}$ methionine/d, whilst the twelve control lambs were infused with a solution of inorganic salts supplying the same amounts of sodium and phosphorus/d as supplied by the sodium caseinate. Further experimental details are given by Barry $(1981 a)$.

Approximately $24 \mathrm{~h}$ before blood samples were taken, PVC indwelling catheters were inseted into the jugular vein using local anaesthetic (Xylocaine; Astra Chemicals, Sydney). For each animal one jugular vein was catheterized for taking endocrine samples and both were catheterized for measurement of glucose production.

\section{Glucose irreversible loss}

Measurements of rate of irreversible loss of glucose were made on seven control and eight protein-infused lambs during week 9 , using dilution of $\mathrm{D}-\left[\mathrm{U}-{ }^{14} \mathrm{C}\right] \mathrm{glucose}(3 \mathrm{mCi} / \mathrm{mmol})$. A priming injection of $20 \mu \mathrm{Ci}$ was given at 10.00 hours, followed by a $5 \mathrm{~h}$ continuous infusion to one jugular vein at $30 \mathrm{ml} / \mathrm{h}$ of a sterile solution containing $0.56 \mathrm{mCi} / 1$ (i.e. $16.8 \mu \mathrm{Ci} / \mathrm{h}$ ). After $3 \mathrm{~h}$, samples were withdrawn from the other jugular vein at $20 \mathrm{~min}$ intervals into heparinized syringes, centrifuged immediately at $4^{\circ}$ and the plasma stored at $-20^{\circ}$. Glucose irreversible loss was calculated from the mean plasma glucose specific activity determined from the last three samples, as described later.

\section{Blood sampling regimens for endocrine studies}

Expt 1. To study effects of protein infusion and of season all lambs were sampled on $1 \mathrm{~d}$ during weeks 4 and 10 . Intake was ad lib. for all samplings, which were carried out at 08.00 and 13.00 hours.

Expt 2. During week 7, pairs of control and protein-infused lambs were selected that had equal herbage intakes. Four pairs were selected. There was some difference between each of the four pairs in absolute intake level, but the selection procedure ensured that mean intake was the same for control and protein-infused lambs. Samples were taken from four pairs on $1 \mathrm{~d}$ at $06.00,08.00,11.00,13.50,15.50,18.00$ and 20.00 hours. The purpose of Expt 2 was first to check that treatment differences detected in Expt 1 in samples taken at 08.00 and 13.00 hours persisted throughout the rest of the day, and secondly to ensure that the 
time-period during which glucose irreversible loss was calculated (14.00-15.00 hours, 5-6 $\mathrm{h}$ after feeding) was a time when hormones which influenced glucose production (glucagon) and utilization (insulin) were at relatively stable concentrations.

Sampling procedures. As the objective was to study effects of nutritional treatments on the concentration of hormones in plasma, a method of blood sampling was devised to minimize erratic changes in hormone concentration due to episodic or 'spike' release of some hormones, and so improve the precision with which nutritional effects could be measured. At each of the sampling times previously stated, blood samples were withdrawn 20 min before, at the stated time and 20 min later and placed on ice. They were centrifuged within $15 \mathrm{~min}$ at $4^{\circ}$ to remove erythrocytes, equal portions of plasma from the three times were pooled at $4^{\circ}$ and then frozen at $-20^{\circ}$ after the last sample had been added. During this pooling procedure the plasma from each lamb was divided so that the subsample for each hormone (generally $1 \mathrm{ml}$ ) was frozen in a separate container. The proteinase inhibitor Trasylol (Bayer, Leverkusen, W. Germany) was added $(1000 \mathrm{KIU} / \mathrm{ml}$ plasma) to the tubes used for glucagon and somatostatin assays and lyophilized before the plasma was added. The pooling procedure used was similar to that recommended by Trenkle (1980) for growth hormone assay.

\section{Laboratory methods}

Plasma concentrations of urea, glucose and non-esterified fatty acids (NEFA) were determined as described by Barry $(1981 b)$. Hormone concentrations were determined using standard radioimmunoassay procedures, with specific modifications for insulin (Albano et al. 1972), glucagon (Unger et al. 1970), thyroid hormones (Saddler \& Brownlie, 1975), somatostatin (Arimura et al. 1978) and cortisol (Fairclough \& Liggins, 1975). Glucose was isolated from plasma and infusate samples as the potassium gluconate derivative (Blair \& Segal, 1960); radioactivity content was determined by liquid-scintillation spectrometry and expressed in relation to glucose content, determined by the glucose oxidase method.

\section{Calculations and statistical procedures}

Rate of glucose irreversible loss was calculated from the formula:

glucose infusion rate (disintegrations per min)

plasma glucose plateau specific activity (disintegrations/min per mg glucose)

Plasma glucose specific activity (SA) attained plateau values by $3 \mathrm{~h}$ after the infusion of $\left[\mathrm{U}-{ }^{14} \mathrm{C}\right] \mathrm{glucose}$ commenced. Variation between successive samplings was minimal during the period 4-5 h after the infusion commenced; consequently the mean of the three measurements of plasma glucose SA in samples taken at $20 \mathrm{~min}$ intervals during this time was used in the above formula to calculate glucose irreversible loss. The time-period when glucose irreversible loss was calculated was therefore 14.00-15.00 hours, corresponding to $5-6 \mathrm{~h}$ after the morning feed was offered.

Endocrine data from Expt 2 were analysed using a split-plot procedure, with protein infusion (i.e. lambs) as main plots and sampling times as sub-plots. An initial examination of endocrine data from Expt 1 using protein infusion as main plots and weeks as sub-plots revealed that the error terms and covariance regressions for each stratum were homogeneous; consequently those data were analysed as a single plot level. For glucose irreversible loss and for the endocrine samples taken in Expt 1 there was a small difference between the two treatment groups in mean herbage ad lib. intake (see Barry, $1981 \mathrm{a}$ ), and also a range of intakes within each treatment due to individual animals attaining different ad lib. intakes. In these instances voluntary intake of herbage digestible organic matter (DOM), measured over the same week that respective plasma samples were taken, was used as a covariate. 
Table 1. Rates of change per unit increase in herbage digestible organic matter (DOM) intake $(\mathrm{g} / \mathrm{d})$ for plasma concentrations of insulin $(\mathrm{mU} / \mathrm{l})$, growth hormone $(\mu \mathrm{g} / \mathrm{l})$ and the molar ratio $T_{4}: T_{3}$

(Values were calculated from the mean of samples taken at 08.00 and $13.00 \mathrm{~h}$, and are the common slope for control and protein-infused lambs over weeks 4 and 10)

\begin{tabular}{lrr}
\hline & \multicolumn{1}{c}{ Slope } & \multicolumn{1}{c}{ SE } \\
\hline Insulin & 0.73 & $0.360^{*}$ \\
Growth hormone & $-0 \cdot 14$ & $0 \cdot 060^{*}$ \\
$\mathrm{~T}_{4}: \mathrm{T}_{3}$ & -0.37 & $0 \cdot 168^{*}$ \\
\hline
\end{tabular}

${ }^{*} P<0 \cdot 05$.

Where use of the covariate gave a significant improvement (i.e. a reduction in the error mean square), treatment effects (control $v$. protein infusion) have been corrected to equal herbage DOM intake and the rate of change/unit DOM also quoted.

\section{RESULTS \\ Voluntary intake}

Mean voluntary intakes of DOM for control and protein-infused lambs over the period of $\left[\mathrm{U}-{ }^{14} \mathrm{C}\right] \mathrm{glucose}$ infusion were respectively 61 and $55 \mathrm{~g} / \mathrm{kg} \mathrm{W}^{0 \cdot 75}$ per $\mathrm{d}(P<0 \cdot 10)$. Corresponding values for Expt $r$ of the endocrine studies were 52 and $47 \mathrm{~g} / \mathrm{kg} \mathrm{W}^{0.75}$ per $\mathrm{d}$ during week 4 and 62 and $54 \mathrm{~g} / \mathrm{kg} \mathrm{W}^{0.75}$ per d during week 10 . Analysis of the intake during the endocrine experiment by a split-plot procedure, using lambs as main plots and weeks as sub-plots, revealed significant effects due to infusion $(P<0.01)$ and to time $(P<0.001)$ with no interaction between infusion and time $(P>0.05)$. The low intakes during week 4 corresponded with organic matter digestibility over this period $(0.73)$ being slightly lower than during weeks 9 and $10(0 \cdot 78)$.

\section{Endocrine measurements}

Expt 1. Hormones whose concentration showed relationships to herbage DOM intake are shown in Table 1. The results are the combined slopes for both control and protein-infused lambs. Similar relationships were obtained for each sampling time, and the results presented were calculated from the mean of the two times $(08.00 \mathrm{~h}$ and $13.00 \mathrm{~h})$. As herbage DOM intake increased, plasma concentration of insulin increased whilst decreases occurred in both growth hormone concentration and the molar ratio, $\mathrm{T}_{4}: \mathrm{T}_{3}(P<0 \cdot 05)$. The decrease in $\mathrm{T}_{4}: \mathrm{T}_{3}$ was caused by trends in $T_{4}$ concentration to decrease and $T_{3}$ concentration to increase as DOM intake increased. Glucagon concentration also tended to increase with increases in DOM intake $(1.36 \pm 1.039 \mathrm{ng} / 1$ per $\mathrm{g})$, but due to the variation encountered the trend failed to attain significance.

There was no difference whatsoever between control and protein-infused lambs in the relationship between herbage DOM intake and plasma concentration of growth hormone and the molar ratio $T_{4}: T_{3}$. There was some slight indication that plasma concentrations of insulin and glucagon increased more with increases in herbage DOM intake in infused compared with control animals, but this trend was nowhere near attaining significance $(P>0.05)$. Plasma insulin and glucagon concentrations were generally higher for proteininfused than for control lambs (Table 2) but due to increased between-animal variability in the samples taken at 13.00 hours when concentrations were greatest, only the differences found at 08.00 hours were significant $(P<0.05)$. Neither of these hormones showed 
Table 2. Concentrations of insulin $(m U / l)$, glucagon $(n g / l)$, growth hormone $(\mu g / l)$, prolactin $(\mu \mathrm{g} / \mathrm{l})$, somatostatin $(\mathrm{ng} / \mathrm{l})$ and cortisol $(\mathrm{mg} / \mathrm{l})$ in jugular plasma as affected by abomasal infusion of casein + methionine and by stage of the experiment

(Except for insulin and glucagon, values are means of samples taken at 08.00 and 13.00 hours)

\begin{tabular}{|c|c|c|c|c|c|c|}
\hline & \multirow[b]{2}{*}{$\begin{array}{l}\text { Sampling } \\
\text { time } \\
\text { (hours)* }\end{array}$} & \multicolumn{2}{|c|}{ Week 4} & \multicolumn{2}{|c|}{ Week 10} & \multirow[b]{2}{*}{$\begin{array}{l}\text { Standard error } \\
\text { of difference } \dagger\end{array}$} \\
\hline & & $\begin{array}{l}\text { Control } \\
\text { lambs }\end{array}$ & $\begin{array}{l}\text { Protein- } \\
\text { infused } \\
\text { lambs }\end{array}$ & $\begin{array}{l}\text { Control } \\
\text { lambs }\end{array}$ & $\begin{array}{l}\text { Protein- } \\
\text { infused } \\
\text { lambs }\end{array}$ & \\
\hline \multirow[t]{2}{*}{ Insulin } & $08 \cdot 00$ & $19 \cdot 7$ & 25.0 & $23 \cdot 5$ & $28 \cdot 3$ & $\begin{array}{r}3.25 \\
\end{array}$ \\
\hline & 13.00 & $39 \cdot 1$ & $53 \cdot 2$ & $52 \cdot 1$ & $58 \cdot 2$ & $11 \cdot 79$ \\
\hline \multirow[t]{2}{*}{ Glucagon } & 08.00 & 145.6 & $173 \cdot 0$ & $145 \cdot 7$ & $160 \cdot 5$ & $12 \cdot 09$ \\
\hline & $13 \cdot 00$ & $166 \cdot 5$ & $210 \cdot 8$ & $177 \cdot 7$ & $169 \cdot 8$ & $27 \cdot 39$ \\
\hline Growth hormone & Mean & $10 \cdot 3$ & 5.9 & $7 \cdot 4$ & 4.6 & $1 \cdot 13$ \\
\hline Prolactin & Mean & $92 \cdot 8$ & $107 \cdot 5$ & $194 \cdot 3$ & $154 \cdot 6$ & $18 \cdot 50$ \\
\hline Somatostatin & Mean & $119 \cdot 2$ & $93 \cdot 1$ & $86 \cdot 3$ & $77 \cdot 3$ & 8.81 \\
\hline Cortisol & Mean & 6.02 & $6 \cdot 68$ & $8 \cdot 51$ & $9 \cdot 39$ & 1.82 \\
\hline
\end{tabular}

* Feed offered as two equal portions at $09.00 \mathrm{~h}$ and $16.00 \mathrm{~h}$.

$\dagger$ Applies to comparisons between control and protein-infused lambs.

Table 3. Concentration of the thyroid hormones thyroxine $\left(T_{4}\right)$ and triiodothyronine $\left(T_{3}\right)$ in jugular plasma $(\mathrm{nm} / \mathrm{l})$ as affected by abomasal infusion of casein +methionine and by stage of the experiment

(Values are means of samples taken at 08.00 and 13.00 hours)

\begin{tabular}{|c|c|c|c|c|c|}
\hline & \multicolumn{2}{|c|}{ Week 4} & \multicolumn{2}{|c|}{ Week 10} & \multirow[b]{2}{*}{$\begin{array}{l}\text { Standard } \\
\text { error of } \\
\text { difference }\end{array}$} \\
\hline & $\begin{array}{c}\text { Control } \\
\text { lambs }\end{array}$ & $\begin{array}{l}\text { Protein- } \\
\text { infused } \\
\text { lambs }\end{array}$ & $\begin{array}{c}\text { Control } \\
\text { lambs }\end{array}$ & $\begin{array}{c}\text { Protein- } \\
\text { infused } \\
\text { lambs }\end{array}$ & \\
\hline $\begin{array}{l}T_{4} \\
T_{3}: T_{3} \\
T_{4}: T_{3}\end{array}$ & $\begin{array}{c}30 \cdot 0 \\
2 \cdot 21 \\
14 \cdot 4\end{array}$ & $\begin{array}{c}50.7 \\
2 \cdot 12 \\
26 \cdot 2\end{array}$ & $\begin{array}{c}25.6 \\
1.63 \\
17.4\end{array}$ & $\begin{array}{c}54 \cdot 3 \\
1 \cdot 55 \\
36 \cdot 0\end{array}$ & $\begin{array}{l}3 \cdot 68 \\
0 \cdot 185 \\
2 \cdot 86\end{array}$ \\
\hline
\end{tabular}

* Applies to comparisons between control and protein-infused lambs.

significant changes between weeks 4 and 10 of the experiment. For all other hormones (Tables 2 and 3) and metabolites (Table 4) measured in Expt 1, separate analyses of variance showed the same treatment effects in samples taken at $08.00 \mathrm{~h}$ and $13.00 \mathrm{~h}$. Consequently, results reported are the means of the two sampling times.

Growth hormone concentrations (Table 2) were consistently lower in the plasma of protein-infused than control lambs $(P<0.001)$ and were also lower in week 10 than in week $4(P<0.05)$. Prolactin was the only hormone to show a protein infusion $\times$ week interaction $(P<0.05)$. The increase in prolactin concentration between weeks 4 and 10 was greater for control $(P<0.001)$ than for protein-infused lambs $(P<0.05)$; also prolactin concentration during week 4 did not differ between the two groups but was lower in protein-infused than control lambs by week $10(P<0.05)$. Somatostatin concentration (Table 2) was reduced by protein infusion $(P<0.01)$ and also decreased from week 4 to week $10(P<0.001)$. Cortisol concentrations were higher in week 10 than week $4(P<0.05)$ 
Table 4. Concentrations on non-esterified fatty acids $(N E F A, \mu m / l)$, glucose $(m g / l)$ and urea $(\mathrm{mg} / \mathrm{l})$ in jugular plasma as affected by abomasal infusion of casein +methionine and by stage of the experiment

(Values are means of samples taken at 08.00 and 13.00 hours)

\begin{tabular}{|c|c|c|c|c|c|c|}
\hline & \multirow[b]{2}{*}{$\begin{array}{c}\text { Sampling } \\
\text { time } \\
\text { (hours) }\end{array}$} & \multicolumn{2}{|c|}{ Week 4} & \multicolumn{2}{|c|}{ Week 10} & \multirow[b]{2}{*}{$\begin{array}{l}\text { Standard } \\
\text { error of } \\
\text { difference* }\end{array}$} \\
\hline & & $\begin{array}{l}\text { Control } \\
\text { lambs }\end{array}$ & $\begin{array}{l}\text { Protein- } \\
\text { infused } \\
\text { lambs }\end{array}$ & $\begin{array}{c}\text { Control } \\
\text { lambs }\end{array}$ & $\begin{array}{l}\text { Protein- } \\
\text { infused } \\
\text { lambs }\end{array}$ & \\
\hline \multirow{2}{*}{ NEFA } & 08.00 & 367 & 346 & 178 & 179 & $50 \cdot 5$ \\
\hline & 13.00 & 115 & 93 & 77 & 112 & 24.0 \\
\hline Glucose & Mean & 807 & 851 & 742 & 800 & 34.9 \\
\hline Urea & Mean & 394 & 444 & 353 & 409 & 34.9 \\
\hline
\end{tabular}

* Applies to comparisons between control and protein-infused lambs.

and tended to be slightly but non-significantly higher in protein-infused lambs than for control lambs.

Plasma $T_{4}$ concentrations were markedly higher in protein-infused than control lambs $(P<0.001)$ and did not significantly differ between weeks 4 and 10 (Table 3). Conversely, plasma $T_{3}$ concentrations were unaffected by the protein infusion but decreased between weeks 4 and $10(P<0.001)$. Due to these changes in $\mathrm{T}_{4}$ and $\mathrm{T}_{3}, \mathrm{~T}_{4}: \mathrm{T}_{3}$ was increased by protein infusion $(P<0.001)$ and increased between weeks 4 and $10(P<0.05)$.

Glucose and urea concentrations (Table 4$)$ were both slightly but significantly $(P<0.05)$ higher in the plasma of protein-infused than control lambs. Plasma NEFA values were unaffected by the protein infusion.

Expt 2. Averaged over all seven sampling times, concentrations of glucose $(P<0.01)$, insulin $(P<0.10)$, glucagon $(P<0.001), \mathrm{T}_{4}(P<0.05)$ and the molar ratio $\mathrm{T}_{4}: \mathrm{T}_{3}$ were greater in the plasma of protein-infused than control lambs. Conversely, plasma growth hormone concentration was reduced by protein infusion $(P<0.05)$. These findings support those of Expt 1, and time trends for these hormones-metabolites (Figs. 1 and 2) show that the effects of protein infusion were apparent at all sampling times and persisted over the $14 \mathrm{~h}$ sampling period studied. No effects attributable to protein infusion could be detected in the other hormones-metabolites measured in Expt 2.

Because of the pooled sampling procedure and the $2 \mathrm{~h}$ interval between samples it is not possible to describe accurately changes in hormone-metabolite concentration with time, but nevertheless some general trends were evident. Following feeding, concentrations of growth hormone decreased whilst that of insulin and the molar ratio, insulin:glucagon (I/G) increased. Somatostatin concentrations remained relatively constant throughout the day (82-106 ng/1), with the highest values (100 and $106 \mathrm{ng} / \mathrm{l})$ occurring in the samples taken at 08.00 and 11.00 hours. Plasma thyroxine-binding globulin binding ratio (TBG.br), a measure of the extent of saturation of the globulin protein system which transports thyroid hormones, was unaffected by either time of sampling or protein infusion (Fig. 2).

Glucose irreversible loss

At ad lib. intake glucose irreversible loss averaged $9.6 \mathrm{mg} / \mathrm{min}$ per $\mathrm{kg} \mathrm{W}^{0.75}$ and did not differ between control and protein-infused lambs (Table 5). There was no relationship at all between plasma glucose concentration and rate of irreversible loss of glucose.

Glucose irreversible loss was positively related to DOM intake, the slope of the 


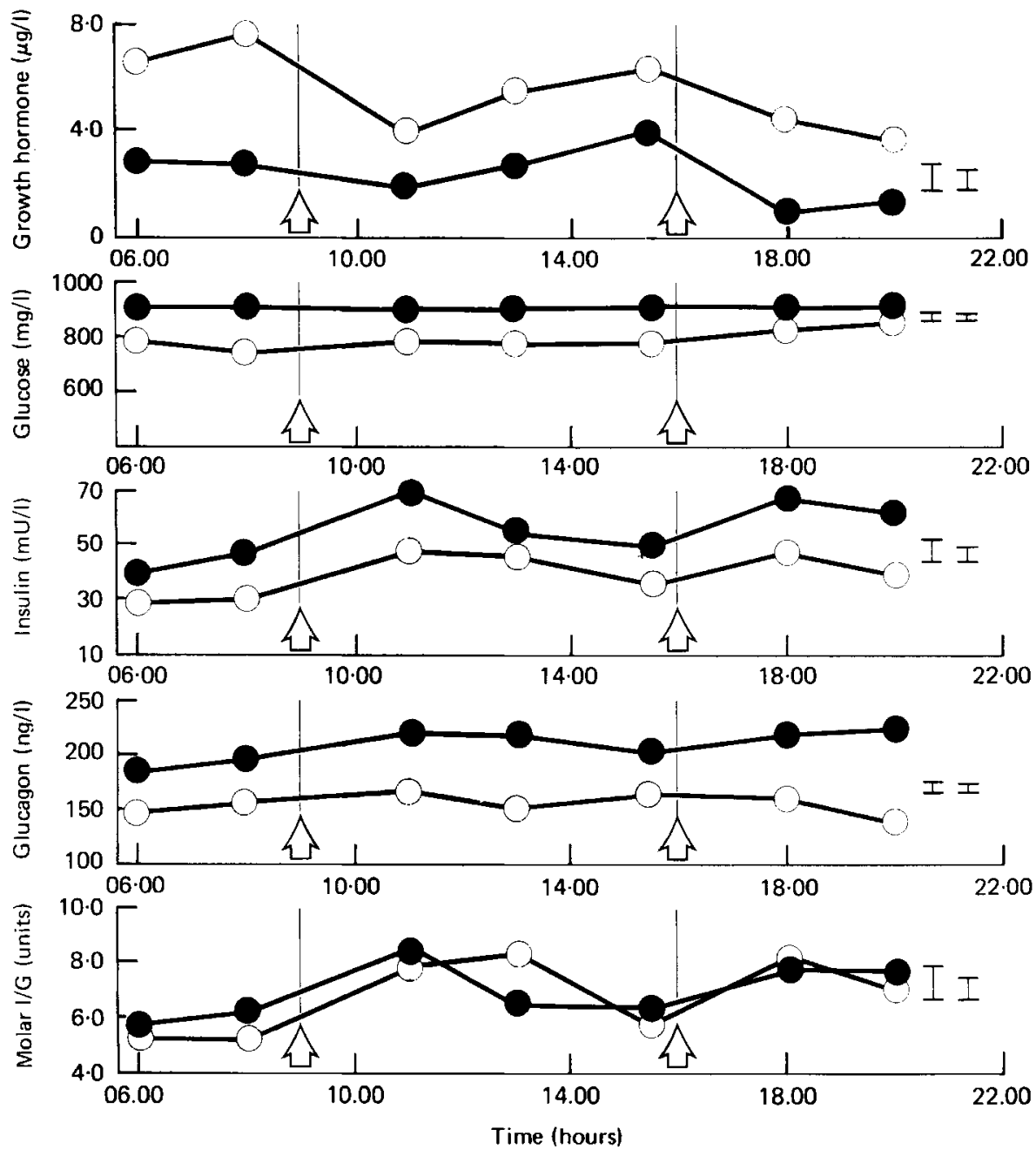

Fig. 1. Concentrations of growth hormone $(\mu \mathrm{g} / \mathrm{l})$, glucose $(\mathrm{mg} / \mathrm{l})$, insulin $(\mathrm{mU} / \mathrm{l})$, glucagon (ng/l) and the molar ratio, insulin: glucagon $(I / G)$ in jugular plasma of groups of four lambs at different times of the day. $(\mathrm{O}-\mathrm{O})$, Control lambs; $(\mathrm{O}-\mathrm{O})$, protein-infused lambs. $\uparrow$ Feed offered; $I$, sE: smaller value, differences between sampling times within a group, larger value, differences between treatment groups at a given sampling time. For the values shown, subsamples taken from individual animals at the times shown on the graphs were pooled with equal volumes from subsamples taken 20 min before and after each time. Separate analyses were carried out on the seven samples so collected from each animal, and the values shown are the means for each group of four animals at each stated time.

relationship calculated from the within-treatment variation being 0.183 (SE 0.0588$) \mathrm{mg}$ glucose $/$ min per $\mathrm{kg} \mathrm{W}^{0.75}$ for each $1 \mathrm{~g}$ increase in DOM intake/ $\mathrm{kg} \mathrm{W}^{0.75}$ per $\mathrm{d}(P<0.01)$. This corresponds to $0.25 \mathrm{~kJ}$ glucose synthesized (not counting the energy cost of synthesis) $/ \mathrm{kJ}$ increase in ME intake.

After correction to equal herbage DOM intake by analysis of covariance using the above relationship, rate of irreversible glucose loss tended to be greater for protein-infused than for control lambs by $0 \cdot 8 \mathrm{mg} / \mathrm{min}$ per $\mathrm{kg} \mathrm{W}^{0.75}$. 

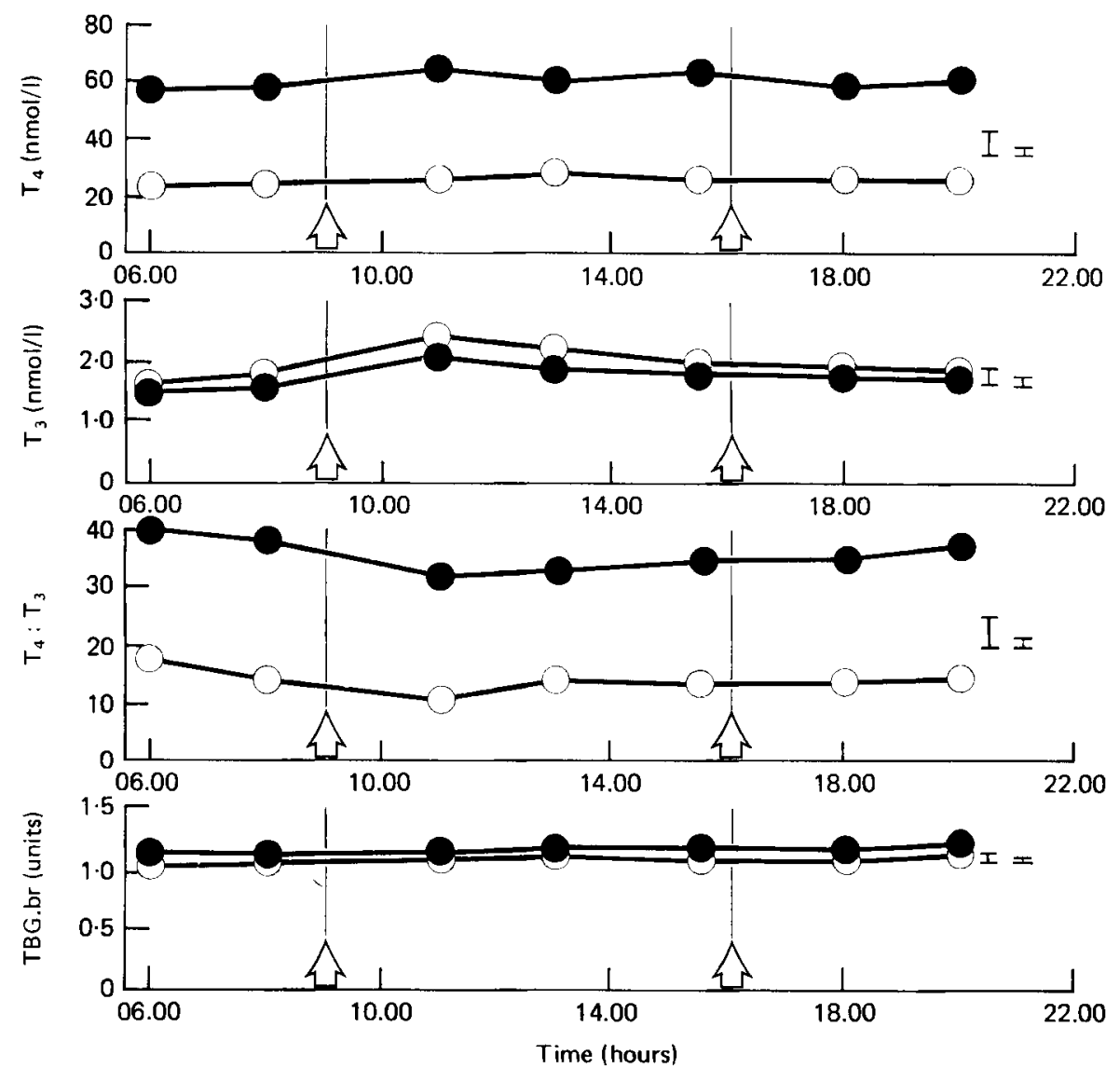

Fig. 2. Concentrations of thyroxine $\left(\mathrm{T}_{4} ; \mathrm{nmol} / \mathrm{l}\right)$, triiodothyronine $\left(\mathrm{T}_{3} ;\right.$ nmol/l), molar ratio, $\mathrm{T}_{4}: \mathrm{T}_{3}$ and $\mathrm{T}_{4}$ binding globulin binding ratio (TBG.br; relative units to pooled human standard) in jugular plasma of groups of four lambs at different times of the day. $(\mathrm{O}-\mathrm{O})$, Control lambs; $(\mathrm{O}-\mathrm{O})$, protein-infused lambs. $\uparrow$ Feed offered; I, sE: smaller value, differences between sampling times within a group, larger value, differences between treatment groups at a given sampling time. For the values shown subsamples taken from individual animals at the times shown on the graphs were pooled with equal volumes from subsamples taken $20 \mathrm{~min}$ before and after each time. Separate analyses were carried out on the seven samples so collected from each animal, and the values shown are the means for each group of four animals at each stated time.

Table 5. Rates of glucose irreversible loss $\left(\mathrm{mg} / \mathrm{min}\right.$ per $\mathrm{kg}$ body-weight $\left.\mathbf{0}^{0.75}\right)\left(\mathrm{W}^{\mathbf{0 . 7 5}}\right)$ as measured at ad lib. intake, and after adjustment of values by covariance to equal herbage intakes

\begin{tabular}{cccc}
\hline \hline Herbage & $\begin{array}{c}\text { Control } \\
\text { lambs } \\
\text { Mean }\end{array}$ & $\begin{array}{c}\text { Protein } \\
\text { infused } \\
\text { lambs } \\
\text { Mean }\end{array}$ & $\begin{array}{c}\text { Standard } \\
\text { error of } \\
\text { difference }\end{array}$ \\
\hline ad lib. & 9.8 & $\begin{array}{r}9.5 \\
10.0\end{array}$ & $\begin{array}{c}0.78 \\
0.60\end{array}$ \\
\hline
\end{tabular}




\section{DISCUSSION}

Protein deposition in this study can be divided into differences between lambs given abomasal protein infusion and control lambs, and to changes with time in wool protein deposition. Both aspects will be discussed in relation to changes in the endocrine system. Changes in circulating levels of insulin, growth hormone and prolactin in sheep and cattle have been shown to reflect changes in their secretion rate rather than changes in turnover (Trenkle, 1971, 1976; Hart et al. 1978a). Hence in this study it is probable that changes in concentrations of these hormones likewise reflect changes in their rate of secretion.

Effects of abomasal protein infusion. Abomasal protein infusion in the lambs fed on fresh pasture $a d$ lib. increased body and carcass growth rates, markedly increased protein deposition in the wool-free body $(14.3 v .8 .7 \mathrm{~g} / \mathrm{d})$, increased wool protein deposition $(6.6$ v. $3.9 \mathrm{~g} / \mathrm{d})$ and increased protein energy as a proportion of total energy retention $(0.41 \mathrm{v}$. 0.27 ) (Barry $1981 a$ ). The major endocrine changes which were associated with this increased protein deposition and changed partition of energy retention were increases in the circulating concentrations of insulin, glucagon and $\mathrm{T}_{4}$ and a decrease in growth hormone concentration. The increased glucagon concentration has relevance to glucose production, which will be referred to later. The other findings are in agreement with those of Hart et al. $(1978 b, 1979)$ for dairy cattle of differing genetic merit, high milk production being associated with high circulating concentrations of growth hormone and low concentrations of insulin and $T_{4}$, whilst increased body-weight gain was associated with low growth hormone and high insulin and $\mathrm{T}_{4}$ concentrations. It therefore seems that a low growth hormone: insulin value accompanied by high $T_{4}$ concentrations is associated with increased rates of body growth and with improved protein deposition.

In animals fed on fresh pasture there are indications that endocrine responses to abomasal protein infusions differ with physiological state. With lactating ewes Barry $(1981 b)$ found that protein infusion increased lactation persistency, especially of net protein secreted, with no effect on wool growth. As in this study, the infusion increased plasma concentrations of insulin and decreased those of prolactin, but in contrast growth hormone concentration and growth hormone:insulin were increased by protein infusion. Growth hormone injections increased milk yield in dairy cows (Machlin, 1973) and a suggested mode of action is to increase the lipolysis of body fat reserves, so increasing the amount of energy available to the mammary gland (Swan, 1976; Bines et al. 1980). Such an action would not enhance body growth, and the endocrine system therefore appears to partition the utilization of absorbed protein in sheep fed on fresh pasture according to physiological need, with milk secretion being highest in priority in lactating animals and protein deposition in body tissues and wool being similar in priority in growing lambs.

In both hypophysectomized and thyroidectomized sheep Ferguson et al. (1965) demonstrated that $T_{4}$ therapy was essential to maintain wool growth, and secondly that increasing the $T_{4}$ dose progressively stimulated wool growth in both these and in intact sheep. The greater wool production of protein-infused compared with control lambs may therefore have been mediated in part through their markedly higher plasma $T_{4}$ concentrations. However, $T_{3}$ is recognized as being much more metabolically active than $T_{4}$ (Wallace, 1979) and circulating levels of $T_{3}$ were not increased by protein infusion. On the contrary, increases in wool growth caused by either increase in day length (week $10 v$. week 4) or by protein infusion tended to be associated with reduced $T_{3}$ levels. There must be some possibility that an increase in $T_{3}$ utilization with increased protein synthesis could cause the fall in concentration. Further experimental work is therefore required on the effect of protein infusion on $T_{4}$ to $T_{3}$ conversion, and on $T_{3}$ turnover and its relationship to protein synthesis.

Seasonal changes in wool protein deposition and their relation to endocrine changes. In this 
study increasing photoperiod was associated with marked increases in wool growth in both groups of lambs (Barry, 1981 a). Such changes in wool growth with day length have been recognized for a long time in New Zealand (Coop, 1953). Plasma prolactin concentration showed a seasonal increase which occurred at the same time as the seasonal increase in wool growth. However, the relationship is unlikely to be causative, as injections of ovine prolactin failed tn increase wool growth in either normal or hypophysectomized sheep (Wallace, 1979). Ferguson et al. (1965) still observed seasonal periodicity in wool growth of hypophysectomized sheep maintained on $\mathrm{T}_{4}$ therapy, further illustrating that a pituitary factor is not involved in this cyclic form of protein deposition. The pineal gland has recently been implicated in seasonal cycles of hair growth and melatonin production suggested as the causative agent (Panaretto, 1979). Pineal function would seem the most appropriate area to examine in future work on endocrine factors governing seasonal changes in wool protein deposition.

Glucose production from protein. After correction to equal herbage DOM intake, glucose irreversible loss tended to be greater for protein-infused than for control lambs. Converting these values to glucose production $(\mathrm{g} / \mathrm{d})$ assumes that the period over which glucose irreversible loss was measured was representative of daily glucose production. This is probably a reasonable approximation, because insulin and glucagon concentrations were stable at this time, glucagon concentration did not markedly increase following feeding and the increase in insulin concentration only lasted for 2-3 h. Also glucose irreversible loss was well correlated with daily DOM intake.

Daily glucose production, corrected to equal herbage DOM intake, was 139 and $151 \mathrm{~g} / \mathrm{d}$ for control and protein-infused lambs. Allowing for the $8 \mathrm{~g} / \mathrm{d}$ extra protein deposition in the protein-infused lambs, the $12 \mathrm{~g}$ glucose/d difference represents approximately $60 \%$ of the maximum yield by gluconeogenesis from the $43 \mathrm{~g}$ casein infused (Clark et al. 1977). Higher plasma glucagon concentrations in the protein-infused lambs probably contributed to this high conversion.

By assuming that amino acids supplied from digestion of the basal diet are converted to glucose with the same efficiency as for casein, net synthesis rates of 17 and $28 \mathrm{~g}$ glucose/d can be calculated to have been derived from protein in control and protein-infused lambs respectively. Thus 0.12 and 0.19 of the glucose produced could have been derived from protein in control and protein-infused lambs, which is a broad agreement with the generalized value of 0.20 suggested by Lindsay (1980) for ruminants.

Mechanisms for regulating endocrine status through increasing protein absorption from the small intestine. The present study confirms that protein absorption can regulate plasma insulin concentration in sheep (Bassett et al. 1971), and extends the number of hormones whose plasma concentration can be regulated in this manner to glucagon, growth hormone and $\mathrm{T}_{4}$, whilst the seasonal rhythm of prolactin secretion can also be modified. In ruminants it is now well established that a principal factor governing protein flow to the intestines is the amount of energy fermented in the rumen. It therefore follows that for a given diet, increases in DOM intake will be accompanied by corresponding increases in protein absorption from the intestines. Hence the increases in plasma insulin and glucagon concentration and decrease in growth hormone concentration with increasing DOM intake may well have been mediated via the accompanying increase in protein absorption from the intestines. The decrease in $T_{4}$ and increase in $T_{3}$ as herbage intake increased within the ad lib. range suggests that such increases in ME intake are accompanied by the conversion of $\mathrm{T}_{4}$ to $\mathrm{T}_{3}$.

The higher plasma $T_{4}$ concentration in protein-infused lambs implies that this treatment must have caused some form of thyroid stimulation. Thyrotrophin-releasing hormone (TRH) has recently been detected in gut and pancreatic tissue of the rat (Morley et al. 1977) 
and one possibility is that TRH secretion from this source could have been stimulated by increasing protein absorption from the small intestine.

Somatostatin was originally proposed to reduce growth hormone release (Bassett, 1975). However, in both this and the lactating ewe work (Barry, 1981 b) there were negative relationships between plasma concentrations or somatostatin and glucagon, which is indicative of glucagon regulation. Such regulation seems feasible, considering the close proximity of somatostatin-secreting and glucagon-secreting cells in the pancreas (Larsson et al. 1979).

The present study has shown that the increased protein deposition resulting from abomasal protein infusion in lambs fed on fresh pasture ad lib. was probably mediated in part by changes in the endocrine system, although the mechanisms by which increased protein absorption produced these endocrine changes are not fully known at this time and require further research.

The authors would like to thank Mrs J. Crosbie and Mrs R. W. Harrex for assistance with sample preparation in the laboratory and with data processing, and $\mathrm{Dr}$ G. H. Jowett for guidance with the statistical analyses. The endocrinology assays carried out at Christchurch were supported in part by the Medical Research Council of New Zealand; the authors specifically thank Mr W. A. Sadler for performing the thyroid hormone assays and Mrs M. Woods for conducting the somatostatin assays.

\section{REFERENCES}

Albano, J. D. M., Ekins, R. P., Marity, G. \& Turner, R. C. (1972). Acta Endocr. $70,487$.

Arimura, A., Lundquick, G., Rothan, T., Chang, R., Fernandez Durango, R., Edde, R., Gog, D. H., Meyers, C. \& Schally, A. V. (1978). Metabolism 27, 1139.

Barry, T. N. (1981a). Br. J. Nutr. 46, 521.

Barry, T. N. (1981 b). N.Z. Jl agric. Res. 23, 427.

Bassett, J. M. (1975). In Digestion and Metabolism in the Ruminant. Proceedings 4th International Symposium on Ruminant Physiology, p. 383 [I. W. McDonald and A. C. I. Warner, editors]. Armidale: University of New England Publishing Unit.

Bassett, J. M., Weston, R. H. \& Hogan, J. P. (1971). Aust. J. biol. Sci. 24, 321.

Bines, J. A., Hart, I. C. \& Morant, S. V. (1980). Br. J. Nutr. 43, 179.

Blair, A. \& Segal, S. (1960). J. Lab. clin. Med 55, 959.

Clark, J. H., Spires, H. R., Derrig, R. G. \& Bennink, M. R. (1977). J. Nutr. 107, 631.

Coop, I. E. (1953). J. agric. Sci., Camb 43, 456.

Fairclough, R. J. \& Liggins, G. C. (1975). J. Endocr. 67, 333.

Ferguson, K. A., Wallace, A. L. C. \& Lindner, H. R. (1965). In Biology of the skin and hair growth, p. 655 [A. G. Lyne and B. F. Short, editors]. Sydney: Angus \& Robertson.

Hart, I. C., Bines, J. A. \& Morant, S. V. (1979). J. Dairy Sci. 62, 270.

Hart, I. C., Bines, J. A., Morant, S. V., Napper, D. J., Danby, K. A. M. \& Black, L. A. (1978a). A. Rep. natn. Inst. Res. Dairy p. 106.

Hart, I. C., Bines, J. A., Morant, S. V. \& Ridley, J. L. (1978b). J. Endocr. 77, 333.

Larsson, L. I., Goltermann, N., Magestres, L., Rehfeld, J. F. \& Schwartz, T. W. (1979). Science N.Y. $205,1393$.

Lindsay, D. B. (1980). Proc. Nutr. Soc. 39, 53.

Machlin, L. J. (1973). J. Dairy Sci. 56, 575.

Morley, J. E, Garvin, T. J., Pekary, E. \& Hersham, J. M. (1977). Biochem. Biophys. Res. Commun. $79,314$.

Panaretto, B. A. (1979). In Physiological \& Environmental Limitations to Wool Growth, p. 327 [J. L. Black and P. J. Reis, editors]. Armidale: University of New England Publishing Unit.

Saddler, W. A. \& Brownlie, B. E. W. (1975). N.Z. med. J. 81, 328.

Swan, H. (1976). In Principles of Cattle Production, p. 85 [H. Swan and W. H. Broster, editors]. London: Butterworths.

Trenkle, A. H. (1971). J. Nutr. 101, 1099.

Trenkle, A. H. (1976). J. Anim. Sci. 43, 1035.

Trenkle, A. H. (1980). In Digestive Physiology and Metabolism in Ruminants. Proceedings 5th International Symposium on Ruminant Physiology, p. 505 [Y. Ruchenbusch and P. Thivend, editors]. Lancaster: MTP Press. Unger, R. M., Aguilar-Paroda, E., Muller, W. A. \& Eisentrout, A. M. (1970). J. clin. Invest. 49, 837.

Wallace, A. L. C. (1979). In Physiological \& Environmental Limitations to Wool Growth, p. 257 [J. L. Black and P. J. Reis, editors]. Armidale: University of New England Publishing Unit. 